Communication research knows no geographic boundaries. Yet, when an American wishes to do communication research or consulting in a foreign country there arise a series of issues that can impede solid investigation. To understand some of the issues along with suggestions on meeting those issues is the purpose of the following article.

\title{
BUSINESS COMMUNICATION CONSULTING AND RESEARCH IN MULTINATIONAL COMPANIES
}

Herbert W. Hildebrandt

The University of Michigan

According to a recent dissertation, ${ }^{1}$ persons in the field of communication are engaged in extensive consulting work. Most of this effort occurs in the U.S., but more persons are pushing their expertise into foreign countries.

This paper suggests that investigating communication problems in multinational companies has its own set of concerns and is more complex than when working for or doing research in American firms.

Our discussion is limited to research and consulting in Germany. But by analogy one may see parallel issues for other countries wherein multinational firms have offices or administrative and manufacturing units.

The topic will be discussed under three headings: 1) qualifications for doing communication consulting-research in German firms; 2) problems of American scholar-researchers in those firms; and 3) suggestions for the American business communication scholar-researcher.

\section{QUALIFICATIONS FOR INTERNATIONAL COMMUNICATION CONSULTANT}

Some definitions are needed. International communication consulting we define as improving international management communication by a qualified person who identifies problems within the headquarters company or subsidiaries, offers appro- 
priate recommendations for action, and transmits these recommendations in written and oral form.

A multinational company can simply be defined as a firm which does business in more than one country. Additionally it means a "world wide corporation registered in several countries, but all controlled by one headquarters."

Thus an immediate inference is that a dimension beyond refined scholarly tools is needed. Lists of consultant characteristics are numerous. One could cite, for example, the fourteen qualities suggested by the Association of Consulting Management Engineers: professional etiquette; stability of behavior; self-confidence; personal effectiveness; integrity; independence; intellectual competence; analytical ability; creative imagination; skill in interpersonal relationship; ability to communicate; and last, psychological maturity. ${ }^{3}$ These are acceptable. We do not disagree. I find little fault.

My qualification list puts command of German first. The popular press skews the situation. Indeed, both students and the profession assume precise English language competence by all German listeners. We are further led to believe that all communication in the business world is English: solely, consistently, unquestioningly. False.

It is true that many German firms transmit their messages in English to the United States and in turn receive telexes in English. Write in English to a German firm and you will often receive a reply in English. Conclusion: the world of German business is English and communication problems are negligible. False.

The preceding presumptions are more true for the upper level manager, usually at the level of the Aufsichtsrat (Board of Directors) or the Vorstand (Executive Committee). But, each managerial step from those positions finds less English language competency in a German firm.

I maintain that knowing German-or any foreign language-will help consulting-research activity in the following ways:

-Written material can be read in the original

-Dolmetscher (translators) in interviews are unnecessary

-Interviewees are more open in their native language

-Credibility of researcher is increased

-Breadth of interviews widened, contacts broader; one can speak with non-English speaking employees

-Informal group meetings develop

-Contacts outside of work environment occasionally occur 
-Breakdowns in communication are fewer

In sum, one's academic research skills are insufficient to overcome the language barrier. Language competence is a must qualification for perceptive multinational consulting or research in the area of communication.

Second, the popular booklet These Strange German Ways ${ }^{4}$ is but a cultural preamble to a highly complex set of human variables. One must go beyond that introductory booklet, knowing something of the political scene; the economy; the history; the people; the traditions - then proceed with one's work. Brief tour books are abundant.

Third, as a direct outgrowth of the preceding, an awareness of managerial differences - a direct relationship to cultural behavior and tradition-should be understood. A naive researcher who presumes that German-American value systems, managerial styles, employee attitudes, work policies, and formal-informal communication systems are identical, is in error. Such naivete is the cause for the problems I shall discuss in the next section.

\section{PROBLEMS OF AMERICAN BUSINESS COMMUNICATION CONSULTANTS IN GERMANY}

From our experience a consultant's task could be as simple as conducting a limited survey. ${ }^{5}$ The scope is narrow. Or, one's work could range from market studies, employee attitudes, to decisionmaking as affected by cultural variables. The list is endless.

One might do a broader management survey. The Geneva office of the International Labor Organization suggests that researchers would recognize the management survey under headings such as management audit; consulting survey; disagnostic survey; diagnostic evaluation; business diagnosis, pilot study, or company appraisal. ${ }^{6}$

Regardless of the business communication consultant's relationship with a German firm, the end product will often be to suggest change. That action demands employee contact, access to information, communication with numerous German employees. Therein lie problems.

\section{Company Control of Information}

Obtaining communication data from German management is more difficult than in American companies. Businesses in the 
United States are more open; numerous reports are public; government regulations insist on extensive disclosure. In German firms there is tighter control of information.

This is not the place to speculate why there is tighter control of information, but a few descriptive comments by German managers might be useful:

-We're concerned that our information will fall into the hands of competitors. We're even hesitant to offer news stories to the Handelsblatt or Wirtschaftswoche.

-We feel that keeping information to ourselves is for our own benefit. When working on an experiment $I$ have no intention of letting my colleagues know about it. They're also my competitors.

-We desire to be separated from our subsidiaries here in Germany and from our subsidiaries in the United States.

-We really need approval to show you anything.

There is a reluctance to provide raw data in written form. Gathering information orally is a bit easier, particularly when knowing the language well.

\section{Variations in Business Procedures}

This generic phrase can be called differences in organizational procedure. Things are just done differently in a German company. This statement does not denegrate German business; Germans in the United States voice similar observations of us. A few examples of German business procedures illustrate our points:

-Dual signatures (often required by law) on letters and documents which leave a company. This dual signing is often true of financial matters.

-Inordinate detail in written reports, especially those ending with a recommendation. A German once admitted that starting with Adam and Eve is frequently the genesis for a German report.

-Psychological and status distance between superior and subordinate, more so if the superior has a Ph.D.

-Autocratic attitudes by superior, notably those persons of an earlier generation.

-Overt and consistent emphasis on nonwork on weekends or beyond the normal quitting time for the day. 
-Vacations as a period of complete release from business; no invasion of vacation time with business concerns.

-Price binding, i.e., a consistent price for items such as automobiles regardless of where you purchase them in Germany.

-Influence of American anti-trust laws on German subsidiaries of American parent firms.

-Co-determination differences; in fact, the entire labormanagement relationship.

Each of the above items has hindered, impeded, and limited the flexibility of the researcher.

\section{Sọciological Factors}

An American researcher will immediately note the strict division between office and home. A German rarely brings his private, personal world to work. In fact it is unlikely that one would be invited to the home of a German manager. Thus the consultant-client relationship is formal, a strictly business relationship.

For Americans with a professorial and doctor title in a German firm there is a pleasant result: one will be treated with esteem and respect. Furthermore, an American's status is raised even more if he speaks German with ease. I note this language factor again because without the language there is little opportunity to speak with persons whose only command is German.

But a status difference between Americans and Germans results in a communicaion gap: an American is unsure of the message received. Is an American consultant being told what he wishes to hear, are the answers truly discriminating, or is there a degree of fear that the response could be used against the German? In a one-time interview, for example, there is no sure way of knowing.

\section{Variable of Time}

Problem solving, decision-making-as measured by our American ethnocentric standards -is slow in German firms. Inordinate time is taken to avoid a wrong decision. "Americans make decisions based on 80 percent of the facts being in; in Germany we strive for 100 percent." That statement is not unusual, or rare.

Hence the consultant-researcher consumes much time. Let me illustrate. 
1. A question is written in the German parent firm. It is to be sent to its American subsidiary. The response requested is to result in a written recommendation. Prior to the question leaving the German firm, lawyers are consulted, German regulations are investigated, appropriate signatures to the cover letter and problem statement are obtained. The language may be German.

2. The message arrives in the United States. A translation is made, often under great time stress. The American manager reads the report, in English. Staff meetings are held, in English. An American staff is assigned to draft a response. Meanwhile the consultant-researcher also interested in the problem loses contact because of the many people involved. Time passes.

3. The response, in English, is sent to the German firm. It is translated into German. Two copies of the report and recommendations are available: English and German. There is no guarantee that the two copies are identical semantically.

4. The recommendations may be unclear. There are accusations that the response does not answer the questions raised. Telexes are sent. Follow-up phone calls occur. Further miniinterpretations develop. Time passes.

My above illustration is oversimplified. The communication problems are far more serious. In fact, should the communication channel be reversed, i.e., a question come for an American parent firm to a German subsidiary, the breakdown possibility is increased because of poor linguistic command by Americans.

Regardless, the time factor affects the American consultantresearcher:

-Following single communication problems between Germany and the United States takes patience, and an inordinate amount of time.

-Innumerable persons are involved in message transmission and message reception.

-Added strain is put on the consulting relationship.

As we leave this section on problems of the American consultant in German firms, let me conclude: 1) secrecy or over-protection control of information is real; 2) German business practices differ, rules differ; a lack of understanding by Americans may presuppose a problem when to the Germans there is no problem; 3) cultural imprints, an ethic of perfection, tradition, habits affect German business; these too demand understanding; 
and 4) consulting work will take longer than originally planned, particularly when the issue involves both the German parent firm and its American subsidiary.

\section{SUGGESTIONS FOR THE AMERICAN CONSULT ANT-RESEARCHER}

By this time the business communication instructor may have lost all interest in consulting for multinational firms: the hindrances are too many, the hurdles too high. Let me offer the following suggestions:

1. It is easier to work with the American subsidiary of a German firm than with the parent company in Germany unless you know the language well.

2. Your consulting contract and retainer might well be based on a previous research article, read by a member of the firm.

3 . Any publication as a result of your investigation should avoid specific references to the firm. No German firm with whom I have worked desires publicity.

4. Be prepared to have your final recommendation promptly read, but slow to be implemented. We have in this paper not spoken of the factor of change in consulting, but an initially felt problem and a subsequent recommendation to solve that problem do not guarantee a change. A commitment to action lies beyond the prerogative of the consultant.

5. Base your consulting on a proposal. Most European firms demand explicit order. They like perfection in documents. It is my suggestion that the following items be covered in your consulting-research proposal:

a. A clear statement of your purpose or goal of the assignment

b. The name of the contract or liaison member in the firm

c. Proposed methodology or chronology of undertaking

- Persons to be contacted

-Travel

- Analysis instruments

-Dates, time

-Possible documents to be viewed

d. Equipment and office space

e. Possible inclusions in briefing document

- Cover letter

-Table of contents 
-Introduction

-Findings

-Recommendations

f. Fee Schedule

g. Resume

6. Maintain the highest personal ethical code. A first breach of confidentiality with a German firm will also be your last. What you learn and hear about is for the consultant alone; not for outside discussion.

Our paper concludes where we began: consulting and doing research in business communication with German and American multinational firms, in Germany, is difficult and complex. But by viewing idea transmission, in a different culture, one can discern both the positive and negative factors in the communication process. The rewards for business communicators are there: for research and for stimulating exchanges with foreign colleagues in the world of business.

\section{NOTES AND REFERENCES}

1. Ritch Eich, Organizational Communication Consulting: A Descriptive Study of Consultant Practices and Prescriptions. Unpublished dissertation, University of Michigan, 1977.

2. Yair Aharoni, "On the Definition of a Multinational Corporation," in The Multinational Enterprise in Transition, ed. A. Kapoor and Philip Grub. Princeton, 1972. p. 17.

3. P. W. Shay, The Common Body of Knowledge for Management Consultants. Association of Consultant Management Engineers, New York, 1974. pp. 41-42.

4. These Strange German Ways. Atlantik-Brücke: Hamburg 10th Edition.

5. For a full discussion of the dynamics of the interaction which occurs between consultant and client, see particularly, Robert R. Blake and Jane Srygley Mouton, Consultation. Scientific Methods, 1976.

6. M. Kubr, ed. Management Consulting A Guide to the Profession. International Labour Office, Geneva, 1976. p. 19. 